\title{
Three Species of the Genus Neolygus Knight (Hemiptera, Miridae) New to Korea
}

\author{
Young Jae Cho, Yong Jung Kwon ${ }^{1 *}$ and Sang Jae Suh ${ }^{2}$ \\ Yeongnam Regional Office, National Plant Quarantine Service, Busan, Korea \\ ${ }^{1}$ School of Applied Bioscience, Kyungpook National University, Daegu, Korea \\ ${ }^{2}$ School of Applied Ecological Resources, Kyungpook National University, Sangju, Korea

\section{단풍교리장늠노린재속(노린재목, 장늠노린재과) 한국미기록종 3종에 대한 보고} \\ 조영재 - 권용정 ${ }^{1 *}$ - 서상재 ${ }^{2}$ \\ 국립식물검역원 영남지원, ${ }^{1}$ 경북대학교 농업생명과학대학 응용생명과학부, ${ }^{2}$ 경북대학교 생태환경대학 생태자원응용학부
}

\begin{abstract}
Three species of the genus Neolygus Knight - N. hakusanensis (Yasunaga, 1991), N. roseus (Yasunaga, 1991) and N. zhugei (Yasunaga, 1991) - are recognized for the first time in Korea. An identification key to the eleven Korean Neolygus species is presented. Some illustrations of male genitalic structures are also provided.
\end{abstract}

Key words: Hemiptera, Miridae, Mirinae, Neolygus

초 록: 단풍고리장님노린재속 N. hakusanensis (Yasunaga, 1991), N. roseus (Yasunaga, 1991)와 N. zhugei (Yasunaga, 1991) 3종의 국내분 포를 처음으로 보고하고, 각 종의 종 동정에 필요한 사진자료와 웅성생식기 그림 및 간략한 형태정보를 기술하였다.

검색어: 노린재목, 장님노린재과, 장님노린재아과, 단풍고리장님노린재속

The genus Neolygus Knight was treated as a subgenus level of Lygocoris Reuter, until Yasunaga, Schwartz \& Chérot (2002) raised it to genus level based upon the comparative morphology of the genitalia. The members of this genus can be easily distinguished by a combination of the following: (1) Body oblongoval; dorsal surface usually pale green. (2) Vertex with distinct basal transverse carina. (3) Pronotum irregularly punctate. (4) Hemelytra declivous posteriorly with an angle to less than 150 . (5) Legs long; tibial spines usually pale. (6) Sensory lobe of left paramere not well-developed basally, with apical protuberance; sensory lobe of right paramere broad, hypophysis terminated in

*Comesponding author: yjkwon@knu.ac.kr

Received October 23 2010; Revised February 22 2011;

Accepted February 242011 a sharp point.

Since Josifov \& Kerzhner (1972) reported the first record of the genus Neolygus as $N$. tiliicola Kulik in Korea, a total of eight species - $N$. aceris, $N$. hoberlandti, $N$. honshuensis, $N$. mjohjangsanicus, $N$. sylvaticus, $N$. tiliicola, $N$. viridis and N. lobatus - have been recorded in Korea (Kwon et al., 2001; Yasunaga et al., 2001). In this paper, we reports three little-known Neolygus species - N. hakusanensis (Yasunaga, 1991), N. roseus (Yasunaga, 1991) and N. zhugei (Yasunaga, 1991) - for the first time from Korea. An identification key for the eleven Korean Neolygus species is provided.

\section{Materials and Methods}

The terminology used in this study follows Yasunaga (1991a) 
and Schuh and Slater (1995). All measurements are in millimeters. The voucher specimens examined in the present study have been deposited in the collection of the School of Applied Bioscience, Kyungpook National University, Daegu, Korea.

\section{Systematic Accounts}

\section{Genus Neolygus Knight, 1917 \\ 단풍고리장님노린재속}

Neolygus Knight, 1917: 561 (as subgenus of Lygus; upgraded by Yasunaga, Schwartz and Chérot, 2002: 1).

Type species: Lygus communis Knight 1917; by original designation.

Key to the Korean species of the genus Neolygus Knight

1. Doral surface reddis N. roseus

-. Dorsal surface not tinged with red 2

2. Apex of tylus pale 3

-. Apex of tylus black 7

3. Vesical ventral sclerite resemble a spicule

-. Vesical ventral sclerite not as above

4. Vesical ventral sclerite as long as a spicule N. aceris

-. Vesical ventral sclerite shorter than $1 / 2$ length of a spicule N. sylvaticus

5. Sensory lobe of left paramere widened

N. zhugei

-. Sensory lobe of left paramere not as above 6

6. Thickness of vesical spicule wider than ventral sclerite at its bottom N. viridis

-. Thickness of vesical spicule narrower than ventral sclerite at its bottom N. hoberlandti

7. Posterior part of pronotum darkened .. 8

-. Posterior part of pronotum pale 9

8. Spicule of vesica strongly curved on the top, apex of ventral sclerite pointed N. honshuensis

-. Spicule of vesica slightly curved, ventral sclerite almost membranous; its apex not pointed N. lobatus

9. Vesical ventral sclerite wide, folded longitudinally at the apex N. hakusanensis

-. Vesical ventral sclerite not as above 10
10. Body less than $5.5 \mathrm{~mm}$ in length, sensory lobe of right paramere with apical conical protuberance

N. tiliicola

-. Body more than $6.0 \mathrm{~mm}$ in length, sensory lobe of right paramere weakly apically protruded

N. mjohjangsanicus

Neolygus hakusanensis (Yasunaga, 1991) 울릉단풍고리장님노린재(신칭)

(Figs. 1A, 2)

Lygocoris hakusanensis Yasunaga, 1991b: 725.

\section{Diagnosis.}

Body uniformly pale brown, slightly elongate; dorsal surface clothed with golden hairs (Fig. 1A). Head pale brown, vertical, with short suberect pubescence; apical half of clypeus blackish; vertex with a distinct medial longitudinal furrow and with distinct basal transverse carina. First and second antennal segments pale brown, except for apex of the latter dark brown.
A

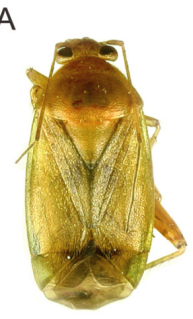

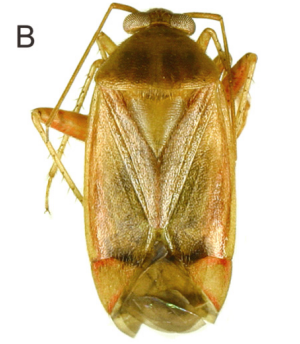

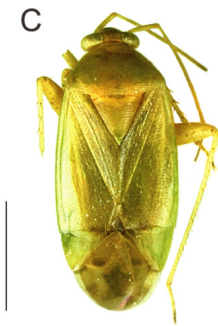

Fig. 1. Habitus of Neolygusspp. A: N. hakusanensis, B: N. roseus, C: N. zhugei. Scale: $2 \mathrm{~mm}$.
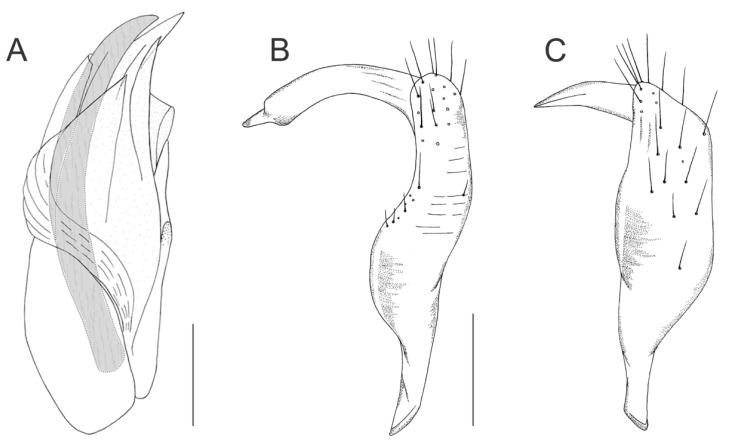

Fig. 2. Male genitalia of Neolygus hakusanensis. A: vesica in dorsal view; $\mathrm{B}$ : left paramere in dorsal view; $\mathrm{C}$ : right paramere in ventral view. Scale: $0.2 \mathrm{~mm}$ 
Labium reaching hind coxae. Pronotum sub-shinning, tinged with green behind calli, densely and rather deeply punctate, covered with short pubescence; pronotal collar pale brown, apparently narrower than basal transverse carina of vertex. Scutellum slightly greenish, indistinctly rugose. Hemelytra almost impunctate, densely covered with decumbent pubescence; Inner apical corner of corium dark brown; cuneus 1.8 times as long as width; membrane grayish brown. Legs pale brown; hind femur with two dark apical rings; tibial spines pale brown; apical part of third tarsal segment dark brown. Abdomen wholly pale brown.

Male genitalia (Fig. 2): vesical spicule broad, almost straight; ventral sclerite wide, with apical pointed process; basal sclerite spinose (Fig. 2A). Sensory lobe of left paramere broad, roundly protruded apically (Fig. 2B). Right paramere rather long, with sensory lobe protruded apically (Fig. 2C).

\section{Measurements.}

$\sigma^{x}$ : Body length 5.55-5.74, head width 1.10-1.22, vertex width 0.35-0.41, Antennal segments I-IV length 0.83:2.01:1.14:0.62, total rostral length 2.32 , pronotal length $1.05-1.08$, pronotal width 1.94-2.07, hind femur: tibia: tarsus length 2.25-2.34:3.0-3.05: 0.75-0.90 and width across hemelytra 2.15-2.38. 우 : Body length 5.50-5.75, head width 1.25-1.32, vertex width 0.35-0.45, Antennal segments I-IV length 0.75:1.75:1.09:0.85, total rostral length 2.30, pronotal length 1.05-1.10, pronotal width 2.10-2.20, hind femur: tibia: tarsus length 2.10-2.25:3.12-3.20:0.71-0.75 and width across hemelytra 2.30-2.54.

\section{Material examined.}

$30^{\top} 2$ ㅇ , Is. Ulleungdo, Gyeongsangbuk-do Province, Korea, 25.vi.2004, YJ Kwon.

\section{Distribution.}

Korea (new record), Japan (Hokkaido, Honshu).

\section{Remarks.}

This species is similar with $N$. tillicola, but it can be considerably distinguished from the latter by the vesical ventral sclerite wide with folded longitudinally at the apex. The vesical ventral sclerite of $N$. tillicola is distinctively unfolded.

Neolygus roseus (Yasunaga, 1991)

빨강단풍고리장님노린재(신칭)

(Figs. 1B, 3)
Lygocoris roseus Yasunaga, 1991a: 605.

\section{Diagnosis.}

Body oblong-oval; uniformly covered with golden pubescence (Fig. 1B). Head pale reddish brown, with irregular pale brown portions, clothed with sparse short hairs; apical part of clypeus blackish; vertex 0.30 times as wide as head, with a weak medial longitudinal sulcus and with distinct basal transverse carina. Antennae pale reddish brown; apex of second, entire third and fourth segments dark brown. Labium pale brown, except for apical part of fourth segment dark brown. Pronotum densely and rather irregularly punctate, clothed with silky hairs, base margined narrow carina; collar slightly wider than basal transverse carina of vertex. Scutellum rugose. Hemelytra pale reddish brown, almost impunctate, densely covered with caducous pubescence; corium and clavus usually darkened posteriorly; cuneus 2.1 times as long as width; membrane grayish brown. Legs pale brown; femur tinged with red; hind femur with two weak dark rings subapically; tibial spines reddish brown. Abdomen pale reddish brown.

Male genitalia (Fig. 3): vesical spicule long, curved subapically; ventral sclerite widened (Fig. 3A). Left paramere long, sharply curved, with sensory lobe lacking apical protuberance (Fig. 3B). Right paramere with sensory lobe broad, roundly projected apically, hypophysis broad, pointed at tip (Fig. 3C).

\section{Measurements.}

$\sigma^{7}$ : Body length 6.05 , head width 1.21 , vertex width 0.28 , Antennal segments I-IV length 0.71:2.20:1.31:0.90, total rostral length 2.34 , pronotal length 1.15 , pronotal width 2.26 , hind

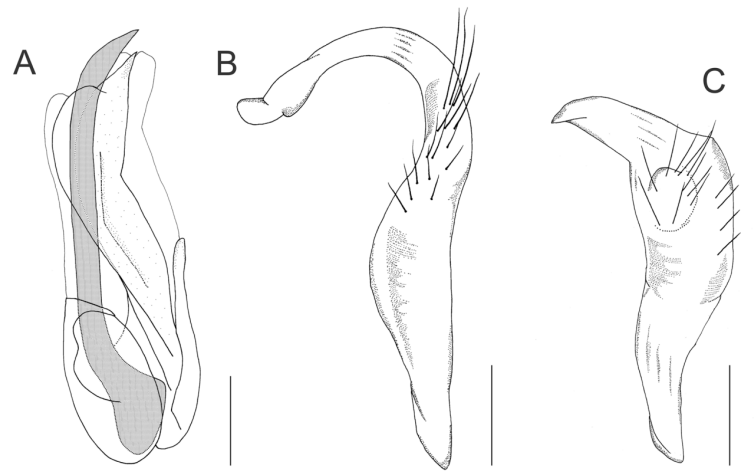

Fig. 3. Male genitalia of Neolygus roseus. A: vesica in dorsal view; $B$ : left paramere in dorsal view; C: right paramere in ventral view. Scale: $0.2 \mathrm{~mm}$ 
femur: tibia: tarsus length 2.25:3.72:0.68 and width across hemelytra 2.57 .

\section{Material examined.}

$10^{7}$, Baekdamsa, Mt. Seolaksan, Gangwon-do Province, Korea, 16.vi.2004, SL An.

\section{Distribution.}

Korea (new record), Japan (Hokkaido, Honshu, Shikoku, Kyushu).

\section{Remarks.}

This species is easily distinguished from other Korean congeneric species by the unique dorsal colouration. In Korea reddish dorsal colouration is not found in other species of Neolygus, which are generally green colored.

Neolygus zhugei (Yasunaga, 1991)

제주단풍고리장님노린재(신칭)

(Figs. 1C, 4)

\section{Lygocoris zhugei Yasunaga, 1991b: 729.}

\section{Diagnosis.}

Body uniformly pale green, oblong-oval; dorsal surface densely covered with golden pubescence (Fig. 1C). Head shining, somewhat tinged with yellow, clothed with short golden hairs; vertex 0.37 times as wide as head in male, 0.39 times in female, with distinct basal transverse carina. First and second antennal segments yellowish brown; apical part of the latter dark in female; third and fourth segments dark brown. Labium pale brown, except for apical part of fourth segment dark brown. Pronotum finely punctate, densely covered with suberect pubescence. Mesoscutum and anterior part of scutellum yellowish.
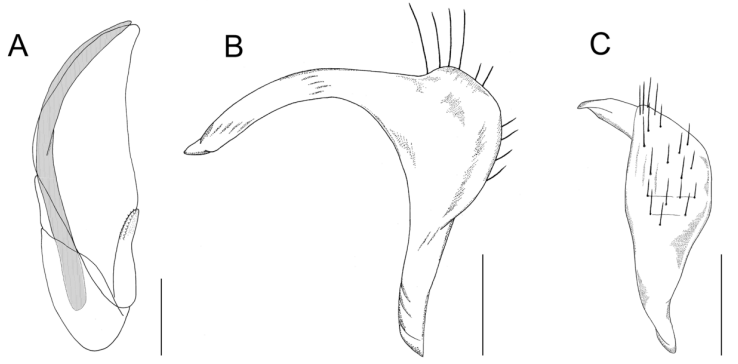

Fig. 4. Male genitalia of Neolygus zhugei. A: vesica in dorsal view; B: left paramere in dorsal view; C: right paramere in ventral view. Scale: $0.2 \mathrm{~mm}$.
Hemelytra pale green, irregularly and shallowly punctate; apex of embolium narrowly dark; cuneus little more than 1.5 times as long as basal width; membrane pale grayish brown. Legs pale green; tibial spines pale reddish brown; apical half of third tarsal segment dark brown. Abdomen generally pale green.

Male genitalia (Fig. 4): vesica lacking ventral sclerite; spicule widened and somewhat flattened subapically; basal sclerite short and small (Fig. 4A). Sensory lobe of left paramere considerably widened, with apical protuberance (Fig. 4B). Sensory lobe of right paramere tumid, hypophysis rather obliquely projected from sensory lobe (Fig. 4C).

\section{Measurements.}

$\sigma^{7}$ : Body length 5.20-5.65, head width 1.10-1.21, vertex width 0.31-0.36, Antennal segments I-IV length 0.78:2.01:1.05:0.86, total rostral length 1.94, pronotal length $0.95-1.12$, pronotal width 1.85-2.05, hind femur: tibia: tarsus length 2.42-2.57:3.00-3.05: 0.73-0.81 and width across hemelytra 2.10-2.46. 우: Body length 5.30-5.70, head width 1.10-1.15, vertex width 0.30-0.32, Antennal segments I-IV length 0.80:2.15:1.32:0.85, total rostral length 1.95, pronotal length 1.10-1.12, pronotal width 2.00-2.10, hind femur: tibia: tarsus length 2.30-2.35:3.40-3.42:0.75-0.80 and width across hemelytra 2.30-2.35.

\section{Material examined.}

$20^{\top} 4$ ㅇ , Mt. Hallasan, Jeju-do Province, Korea, 11.vi.1994, YJ Kwon; $100^{\top} 7$ \& , Mt. Hallasan, Jeju-do Province, Korea, 19.vi.1994, YJ Kwon.

\section{Distribution.}

Korea (new record), Japan (Honshu, Shikoku).

\section{Remarks.}

This species is easily distinguished from other Korean congeneric species by the sensory lobe of left paramere which is distinctively widened with apical protuberance.

\section{Acknowledgements}

The authors are very grateful to Dr. S.L. An (National Science Museum, Daejeon, Korea) for offering the valuable specimen.

\section{Literature Cited}

Josifov, M. and I.M. Kerzhner. 1972. Heteroptera aus Korea. I Teil (Ochteridae, Gerridae, Saldidae, Nabidae, Anthocoridae, Miridae, 
Tingidae, und Reduviidae). Ann. Zool. Wars. 29: 147-180.

Knight, H.H. 1917. A revision of the genus Lygus as it occurs on America North of Mexico, with biological data on the species from New York. Cornell Univ. Agr. Exp. Stat. Bull. 391: 555-645.

Kwon, Y.J., S.J. Suh and J.A. Kim. 2001. Hemiptera. Econ. Ins. Kor. 18. Ins. Kor. Suppl. 25. The National Institute of Agricultural Science, Seoul. 513 pp.

Schuh, R.T. and J.A. Slater. 1995. True bugs of the world (Hemiptera: Heteroptera). Corn. Univ. Press, Ithaca and London, 336 pp.

Yasunaga, T. 1991a. A revision of the plant bug, genus Lygocoris Reuter from Japan, Part I (Heteroptera, Miridae, Lygus-complex).
Jap. Journ. Ent. 59: 435-448.

Yasunaga, T. 1991b. A revision of the plant bug, genus Lygocoris Reuter from Japan, Part II (Heteroptera, Miridae, Lygus-complex). Jap. Journ. Ent. 59: 593-609.

Yasunaga, T., M.D. Schwartz and F. Cherot. 2002. New genera, species, synonymies, and combinations in the "Lygus complex" from Japan, with discussion of Peltidolygus Poppius and Warrisia Carvalho (Heteroptera: Miridae: Mirinae). Am. Mus. Nov. 3378: $26 \mathrm{pp}$.

Yasunaga, T., M., Takai, T. Kawasawa and Y. Nakatani. 2001. A field guide to Japanese bugs II, terrestrial heteropterans. Zenk. Nos. Kyoiku Kyok., Publishing Company, Tokyo, 350 pp. 